\title{
Angelina Branković - święta władczyni w hymnografii. Zarys problemu
}

\begin{abstract}
Gapska Dominika, Angelina Branković - święta władczyni w hymnografii. Zarys problemu (Angelina Branković: the Holy Ruler in Hymnography. Outline of the Problem). „Poznańskie Studia Slawistyczne” 5. Poznań 2013. Adam Mickiewicz University Press, pp. 103-115. ISBN 978-83-232-2636-9. ISSN 2084-3011.

The aim of this article is to present the idea of divinity of power on an example of the medieval service, dedicated to the Serbian despotess Angelina Branković. The image of a ruler and a concept of power presented in the text are based on the perception of Angelina as a participant and a heiress of the sacred tradition of Brankovic dynasty. The service has played an important role in the creation and strengthening of the ruler image in the spiritual culture of the Orthodox Serbs. In addition to strictly liturgical function, it also served as a way of transmission of the elementary set of national religious and political ideas. Hymnography dedicated to St. Angelina was a response to the social and religious needs to canonize the native saints who certify God's care for Serbia in the period of slavery, strengthen the national spirit, contribute to stabilizing the situation in the country.
\end{abstract}

Keywords: Serbian Orthodox Church; the Serbian hymnography; St. Angelina Branković; divinity of power; Serbian female saints; topos of a ruler

Idea boskości władzy ukształtowała polityczne i duchowe oblicze średniowiecznej Serbii. Pierwsze kulty narodowych świętych, Stefana Nemanji (Simeona) i Savy, utrwalone przez hagio- i hymnografów, odzwierciedlają biblijną/chrześcijańską ideę wybrania i posłannictwa, opierając się na zasadzie imitatio Christi. Z teologicznego punktu widzenia Chrystus jest nie tylko wzorcem moralnym, lecz oddziałuje i przemienia człowieka przede wszystkim w sensie ontycznym (Hryniewicz 1982: 399). Święta para założycielska, Simeon i Sava, w dziejach duchowości i państwowości serbskiej stała się symbolem interakcji i dialogu między sacrum i profanum. Jako uczniowie Chrystusa podlegli oni ontycznej przemianie, a ich 
kulturowa, polityczna, duchowa działalność była wzorem dla kolejnych pokoleń serbskich władców. Idea władzy, cerkiewnej i państwowej, nadanej z Bożego pomazania oraz cudowna moc relikwii świętych utrwaliły w serbskiej kulturze myślenie o niezwykłej łączności kraju ze sferą sacrum i jego dziejowej roli, a także narodzie-theoforze przewodniczącym powszechnemu zbawieniu. Działalność świętej pary nabrała zatem również charakteru soteriologicznego. Serbia, symbolicznie ukazywana jako Nowy Izrael, miała stanąć na straży świętości i być na Bałkanach przedmurzem chrześcijaństwa. Za sprawą św. Savy i św. Simeona ukształtowała się charakterystyczna dla serbskiej kultury idea charyzmatycznej dynastii, wyobrażona w postaci ,świętej lozy Nemanjiciów” (święty krzew winny, za J 15,1-8): „Serbska loza stanęła na straży świętości, czy choćby uświęcenia Ziemi i narodu, doprowadzając w końcu do ukonstytuowania się idei wybrania tego ostatniego, wyznaczając jednocześnie jego duchowe uniwersum" (Lis 2004: 119). Swą przynależność do świętej lozy podkreślały kolejne serbskie rody, genealogicznie niezwiązane bezpośrednio z Nemanjiciami: Hrebeljanoviciowie, Krotomianiciowie, Lazareviciowie i Brankoviciowie. W ten sposób sankcjonowały i legitymizowały boskość swojej władzy.

Idee świętej tradycji dynastycznej kontynuuje także kult Angeliny Branković, żony despoty Stefana $(1417-1476 ; 1458-1459)$, matki despoty Đorđa (mnicha Maksima, metropolity wołoskiego, arcybiskupa belgradzkiego; 1461-1516) i Jovana (?-1502) oraz córki Mary.

O Angelinie Branković wiadomo niewiele; urodziła się około roku 1440 na terytorium Albanii jako jedyne dziecko Jerzego (Golema) Arianity Komnena (ok. 1400-1461; 1383-1462) z jego małżeństwa z Marią Muzaką. Ród był zasłużony w walce z Portą - Jerzy wzniecił powstanie przeciw Imperium Ottomańskiemu (1432-1436). Małżeństwo ze ślepym despotą Stefanem Brankoviciem (1417-1476; 1458-1459) Angelina zawarła prawdopodobnie w 1460 roku. Po upadku Smedereva cała rodzina schroniła się we Włoszech (region Friuli), gdzie Stefan zmarł w 1476 roku (Һоровић 2001: 376). Nie wiadomo dokładnie, jak długo po jego śmierci Angelina tam przebywała. Pewne jest natomiast, że w 1486 roku wróciła do Sremu na wezwanie węgierskiego króla Macieja Korwina, od którego rodzina otrzymała posiadłości w pobliżu Kupinova. Synom dano ponownie prawo używania tytułu despoty, zobowiązując jednocześnie do służby wojskowej i ochrony węgierskich granic przed Turkami (Самарџић, Веселиновић, 


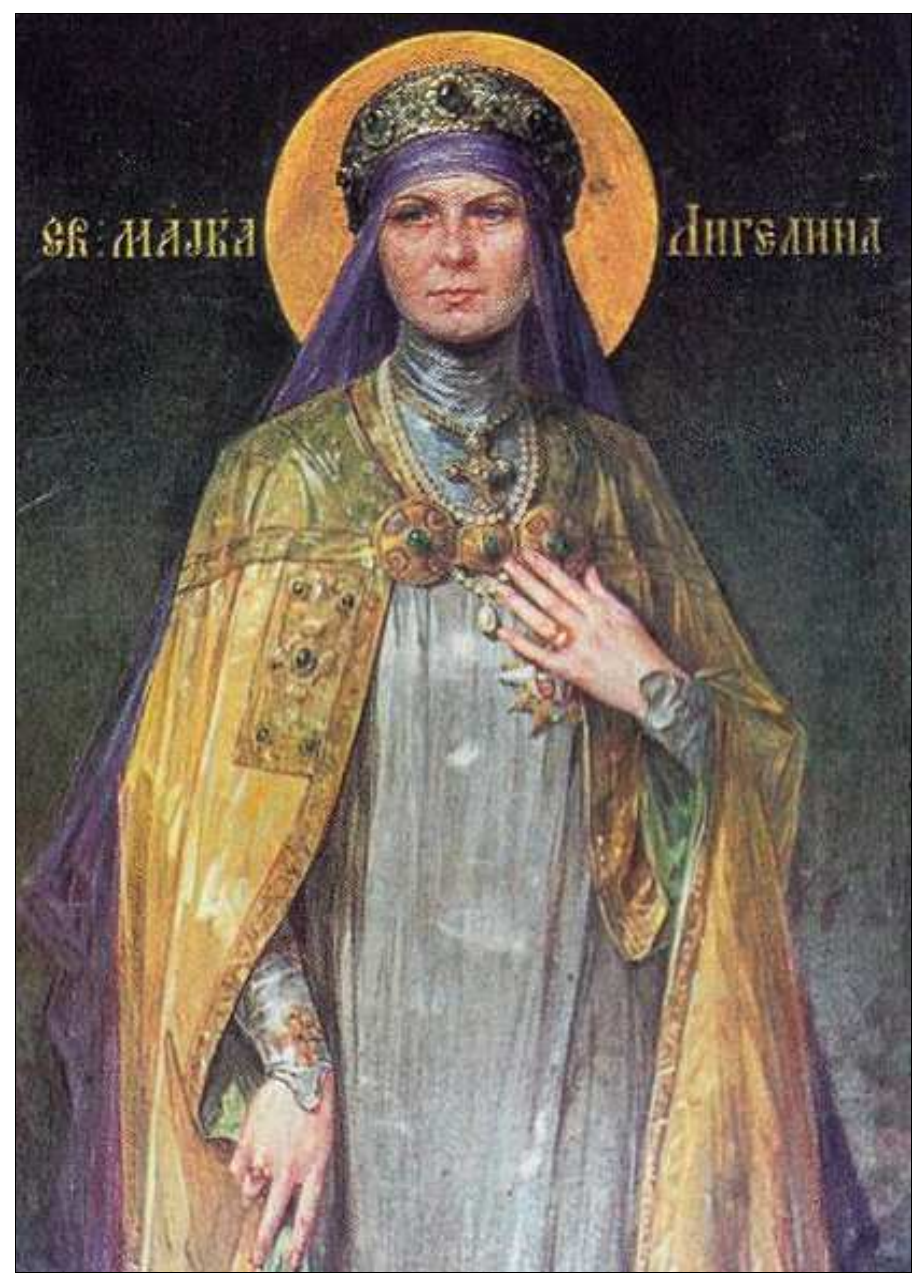

P. Jovanović, Despotica Angelina Branković, (1905-1906, olej na płótnie) Oryginał znajduje się w cerkwi św. Mikołaja w miejscowości Vršac.

Поповић 2000: 131). Względnie spokojne życie Brankoviciów zakłóciła śmierć młodszego syna Jovana w 1502 roku. Angelina, wraz z synem Đorđem, już wtedy mnichem Maksimem (od ok. 1497 roku), powtórnie została zmuszona do udania się na wygnanie, tym razem na Wołoszczyznę, do 
hospodara Radu IV Wielkiego (1467-1508; 1495-1508). Obawiając się zbezczeszczenia przez Turków ciał Stefana i Jovana, którym wówczas przypisywano rangę relikwii, zabrała je ze sobą w podróż. W niedługim czasie Maksim stał się znaczącą osobistością na Wołoszczyźnie i otrzymał funkcję metropolity wołoskiego (Самарџић, Веселиновић, Поповић 2000: 131). Zaangażował się również w działalność dyplomatyczną z ramienia wojewody Radula. Sytuacja uległa zmianie w 1509 roku, kiedy hospodarem wołoskim został Mihnea I Zły (?-1510; 1509-1510), syn Włada Palownika (1431-1476; 1448, 1456-1462 oraz 1476). Nowy władca nie był przychylny Brankoviciom, w związku z tym postanowili raz jeszcze udać się w podróż i przez Budę powrócili do Sremu. Relikwie męża i syna Angelina złożyła w monasterze Krušedol (Томин 2009: 5). Przypuszcza się, że jeszcze przed rokiem 1509 i powrotem do Sremu Angelina przeszła w mniszy stan w monasterze Obeda (fundacja Maksima Brankovicia z 1501 roku), o czym świadczyć ma jej podpis „,смерна монахиња" (Томин 2009: 9, 11, 12) w liście, który wysłała do księcia moskiewskiego Wasyla III (1479-1533; 1505-1533). Ostatnie lata życia spędziła w żeńskim klasztorze w Krušedolu. Zmarła prawdopodobnie w 1520 roku (Томин 2009: 9; Павловић 1965: 152) i spoczęła w przyklasztornej cerkwi Spotkania Pańskiego, którą sama ufundowała. Gdy kilka lat później okazało się, że ciało zmarłej pozostało w grobie nienaruszone, uroczyście przeniesiono je do klasztoru Krušedol i złożono razem ze szczątkami męża i synów (Томин 2009: 90). W roku 1716 z zemsty za przegraną bitwę Turcy spalili klasztor i doczesne szczątki Brankoviciów. Do dzisiaj zachowała się lewa ręka Angeliny, która jest przechowywana w Krušedolu (Павловић 1965: 154).

Cały ród despotów kultywował tradycje opieki nad Cerkwią zapoczątkowane przez dynastię Nemanjiciów, zakładał monastery i cerkwie, wspierał je finansowo. W roku 1486 i 1496 Brankoviciowie wydali też przywileje dla monasteru Chilandar. Akt ten, według Svetlany Tomin, miał charakter programowego gestu i wskazywał na duchowo-ideologiczny związek między dwoma dynastiami (Томин 2011: 182). Angelina i Jovan w 1499 roku obdarowali jeszcze jeden atoski monaster, Esfigmenu (Esphigmenou), założony w V wieku przez bizantyjską cesarzową Pulcherię, prawdopodobnie, by wesprzeć jego odbudowę po splądrowaniu przez piratów i pożarze z czternastego wieku. Zdaniem Momčilo Spremicia, Bran- 
koviciowie byli po Nemanjiciach najhojniejszymi darczyńcami atoskich monasterów (Спремић 1997: 98). Działalność fundatorska wpisała dynastię Brankoviciów w ramy świętosawskiej tradycji jako jej spadkobierców i kontynuatorów. Wyznaczała ona kierunek, pod względem ideowym, jasno zadeklarowanej cerkiewno-politycznej działalności, która zogniskowała się wokół pamięci o świetności przodków i prawosławnej wiary.

Troską o doczesne szczątki zmarłego męża i synów, o ich godny pochówek w ojczyźnie po latach tułaczki poza granicami Serbii, Angelina zapoczątkowała ich liturgiczny kult. Niedługo po śmierci (1520) również jej samej zaczęto oddawać cześć, nazywając „matką Angeliną”. Potwierdza to hagiografia (2 żywoty krótkie ${ }^{1}$ ) (Павловић 1965: 152, 154) i szesnastowieczne oficjum (służba) ku jej czci, napisane prawdopodobnie w środowisku monasteru Krušedol. Zachowany do dziś oryginał tekstu przechowywany jest w Muzeum Serbskiej Cerkwi Prawosławnej w Belgradzie pod numerem 164. Nieznany jest autor nabożeństwa - jedyną wskazówkę odnoszącą się do jego osoby znaleźć można w trzeciej sticherze na „Chwalcie...”, gdzie wspomniano krušedolski klasztor, z którym najpewniej twórca był związany (Gil 1995: 72). Oficjum odegrało ważną rolę $\mathrm{w}$ procesie kreowania i utrwalania wizerunku świętej władczyni w kulturze duchowej prawosławnych Serbów. Poza funkcją stricte liturgiczną od początku służyło też przekazywaniu wiernym elementarnego zestawu narodowych idei religijno-politycznych. Jako jedyne spośród oficjów dedykowanych świętym Serbkom zostało ono zamieszczone we wszystkich wydaniach Srbljaka (1714, 1761, 1765, 1861 i 1986), który stał się wyrazem dążeń Serbskiej Prawosławnej Cerkwi do podtrzymania rodzimej tradycji, pomimo zmiennych i burzliwych losów państwa i Kościoła w ciagu wieków. W najstarszych edycjach Srbljaka - zbiorze z Rakovca (1714) i Rimnika (1761) - Oficjum znajduje się wśród tekstów stanowiących klamrę łączącą utwory dedykowane władcom Serbii z tzw. okresu Raškańskiego, z hymnografią poświęconą dynastii Brankoviciów w roli kontynuatorów tradycji duchowych i politycznych (Gil 1995: 34). Arcybiskup Mihailo, przygotowując kolejne publikacje Srbljaka, tzw. belgradzkie (1861), zamieścił tekst nabożeństwa wśród utworów nowo dodanych do

\footnotetext{
${ }^{1}$ Starszy żywot prologowy został zamieszczony w Srbljaku rimničkim, a nowszy, który nieznacznie różni się od poprzedniego, napisał w XIX wieku metropolita Mihailo, przygotowując belgradzkie wydanie Srbljaka (Gil 1995: 71).
} 
wcześniej istniejącego korpusu. Powodem takiego przesunięcia były wahania hierarchy związane $\mathrm{z}$ drukiem hymnografii dedykowanej świętym kobietom Cerkwi serbskiej, dla której nie widział tam miejsca, jak wynika z jego listu do archimandryty Hrisanta z Peci (Gil 1995: 82-84). W popularnonaukowym wydaniu Srbljaka (1970b), zredagowanym dzięki staraniom Đorđe Trifunovicia, Oficjum Angelinie zostało przygotowane z myślą o szerokim gronie czytelników i w celach popularyzatorskich. Autorzy tomu zebrane teksty podali $\mathrm{w}$ uwspółcześnionym zapisie, paralelnie zamieszczając nowoserbskie wersje utworów ${ }^{2}$. W Srbljaku z połowy lat 80. dwudziestego wieku nabożeństwo poświęcone św. Angelinie jest jednym z czterech dedykowanych serbskim władczyniom ${ }^{3}$, które stały się symbolami przełomowych momentów w dziejach narodu: św. Ana Nemanjić - początku niezależności państwowej i cerkiewnej, św. Eugenia-caryca Milica - klęski na Kosowie, św. Angelina - upadku Despotoviny, a św. Zlata Meglenska - walki narodowowyzwoleńczej z Turkami.

Hymnografia służąca oprawie kultu św. Angeliny była odpowiedzią na społeczną i religijną potrzebę wynoszenia na ołtarze kolejnych rodzimych świętych, którzy poświadczaliby Bożą opiekę nad Serbią w okresie niewoli, umacniali narodowego ducha, przyczyniali się do stabilizowania sytuacji kraju. Pierwsze dziesięciolecia szesnastego wieku sprzyjały takim działaniom, upływały bowiem pod znakiem względnego spokoju, załagodzenia konfliktów między Serbami a Portą. Nie otrzymawszy zagranicznej pomocy, Serbowie doszli do wniosku, jak pisze Đoko Slijepčević, że walka zbrojna jest daremna i zaprzestali działań, rozpoczętych bitwą nad Maricą w 1371 roku (Слијепчевић 2002: 212).

Angelina i pozostali członkowie dynastii Brankoviciów, jako ostatni władający niezależną Serbią oraz kontynuatorzy świętosawskiej i kosowskiej tradycji namaszczeni do pełnienia tej funkcji przez Boga, wykreowani zostali na patronów idei duchowego i politycznego odrodzenia narodu. Hymnografia, którą reprezentuje Oficjum ku czci św. Matki Angeliny, od-

\footnotetext{
${ }^{2}$ Cytując fragmenty Oficjum w niniejszym artykule korzystam z uwspółcześnionego zapisu języka cerkiewnosłowiańskiego zaproponowanego przez Đ. Trifunovicia. Polski przekład urywka pieśni IV kanonu Stużby świętej Angelinie Branković (Dar słowa 1983: 167).

${ }^{3}$ Angelina nie jest pierwszą, ani jedyną świętą serbską władczynią, łącznie kanonizowano ich siedem, począwszy od Any Nemanjić, a skończywszy na Jelenie Štiljanović.
} 
zwierciedla zwrot w kierunku własnej tradycji i duchowości. Jej jaskrawym przykładem jest próba przywrócenia patriarchatu w Peci, stolicy św. Savy, podjęta przez smederewskiego metropolitę Pavla w pierwszych dziesięcioleciach szesnastego wieku (Слијепчевић 2002: 212-213). Toczone są dyskusje, na ile była to próba udana. Zwolennicy pozytywnych rezultatów tego wydarzenia twierdzą, że dowodzi ich restytucja patriarchatu oraz zdecydowane kroki przeciw inicjatorowi przedsięwzięcia, jakie podją arcybiskup ochrydzki Prochor w 1532 i 1541 roku $^{4}$, zwołując dwa synody, w celu zapobieżenia usamodzielnianiu się serbskiego Kościoła. Rozpiętość czasowa między synodami nasuwa przypuszczenie, że Pavle zasiadł na tronie patriarszym wcześniej niż mianowany w 1557 roku Makarije (Грујић 1928: 260; Ћоровић 2001: 416-417). Posunięcie metropolity Pavla, uważane wówczas za bunt wobec Ochrydy, zwróciło uwagę Porty na serbskie dążenia do odnowy autokefaliczności Cerkwi, ale ona nie starała się im zapobiec. Należy podkreślić, że władze tureckie w swej polityce wobec państw podległych kierowały się prawem szariatu, uznającym nierozdzielność życia świeckiego i religijnego, co zapewniało Serbom względną tolerancję religijną, a w szerszym kontekście przyczyniło się również do przychylności Porty wobec odnowy patriarchatu w 1557 roku, który przejął rolę duchowego i politycznego przywódcy narodu. Vladimir Ćorović i Đoko Slijepčević podkreślają, że początek szesnastego wieku sprzyjał rozwojowi piśmiennictwa, powstało wiele ksiag drukowanych nie tylko poza granicami kraju, np. w Wenecji (drukarnia Božidara Vukovicia, 1519-1538), lecz również w rodzimych drukarniach, w Mileševie, Goražde, Gračanicy, Rujnie i Belgradzie (Һоровић 2001: 416; Слијепчевић 2002: 200-204).

Wysoką pozycję Angeliny Branković w gronie serbskich świętych potwierdza liczba dni jej pamięci; wspominana jest indywidualnie 30 lipca, a także podczas obchodów wspólnego święta rodu 10 grudnia. Jej imię pojawia się również w hymnografii poświęconej innym Brankoviciom: w służbie ku czci syna Jovana (10 grudnia), w oficjum całemu rodowi (Павловић 1965: 153).

Đorđe Trifunović sądzi, że datę powstania samodzielnego Oficjum ku czci św. Angeliny należy sytuować między rokiem 1520 a 1530, czyli nie-

\footnotetext{
${ }^{4}$ Stanowiska badaczy są w tej kwestii podzielone, cf. Слијепчевић 2002: 212-213.
} 
długo po jej śmierci (jeśli za właściwą datę przyjmiemy 1520 rok) lub zaledwie 10 lat później (Трифуновић (red.) 1970a: 331). Formuje ono jednak tylko część wizerunku świętej, fragment odpowiedzialny głównie za jej wyobrażenie jako mniszki, w którym cechy modelu świętej władczyni reprezentowane są $\mathrm{w}$ mniejszym stopniu ${ }^{5}$. Na całościowy obraz składają się wszystkie utwory, w jakich występuje. Oprócz hagiografii ważna jest zwłaszcza hymnografia poświęcona Jovanowi Brankoviciowi.

Fundament koncepcji władzy i obraz panującej zasadzają się na postrzeganiu Angeliny w roli współdziedziczki i współuczestniczki świętej tradycji dynastycznej Brankoviciów po Nemanjiciach, najwyraźniej pokazanej w utworze dedykowanym Jovanowi. W łańcuchu duchowych spadkobierców wymieniona jest za św. św. Savą, Simeonem, Stefanem i Maksimem $^{6}$. Rola żony i matki sytuuje ją w centrum rodowodu, nadając funkcję kontynuatorki sakralnej historii serbskich władców i przekazicielki świętego depozytu następnym pokoleniom; imię syna Jovana autor tekstu podaje dopiero po imieniu matki. Do świętej ma tu zastosowanie tradycyjny symbol winnego krzewu, który jest sadzony i pielęgnowany ręką Boga, by wydał podobne sobie latorośle (J 15,5), szczepy winne, owoce winnicy (winne grona), czy odrośle oliwne - znaki Bożego wybrania, błogosławieństwa, dobrobytu, powodzenia dla dynastii, jej kraju i poddanych. To samo znaczenie ma obraz drzewa zasadzonego nad płynącą wodą, które wydaje owoc $\mathrm{w}$ swoim czasie, a jego liście nigdy nie więdną (Ps 1,1-3; Jr 17,5-8) ${ }^{7}$, albo płodnej ziemi, do których porównano matkę w służbie ku jej $\mathrm{czci}^{8}$. Boską genezę wszystkich królewskich dynastii Serbii i ich nadprzyrodzonego, mesjańskiego posłannictwa dla świata wyraża ponadto idea „rodów ostatnich”, będąca transformacją biblijnego obrazu czasów

\footnotetext{
${ }^{5}$ Poetycka charakterystyka świętej jako mniszki jest skonwencjonalizowana i powtarza toposy utrwalone w hymnografii. Tekst charakteryzuje się minimalną liczbą faktów historycznych z życia władczyni.

${ }^{6}$ Wielka wieczernia (dalej: WW), chwała, ton 6. Podobnie w chwale po sticherach na litii, ton 5: „niech dziwią się narody łasce, jaką ponownie otrzymaliśmy, niech zdobi się święta cerkiew Bożej Matki, która ma na początku oparcie w Simeonie i Savie, a teraz w Stefanie, despocie, i wielebnej Angelinie".

${ }^{7}$ „Z korzenia dobrego wyrosłaś i gałęzie dobre rodzisz, jesteś jak drzewo zasadzone u ujścia wód, które przyniosło swój owoc Bogu, a jego liście oparły się diabelskim wiatrom, nas w cieniu swych gałęzi zgromadź”, WW, stichera na „Do Ciebie wołam, Panie”, ton 6.

${ }^{8}$ WW, stichera 2 na „Do Ciebie wołam, Panie”, ton 6; kanon III, 4.
} 
(dni) ostatnich (Pwt 28,13; Hbr 1,2), który jednocześnie przekazuje ideę wiecznej trwałości dynastii oraz ich dziedziny pod Bożą opieką. Każda z wymienionych wyżej figur zawiera perspektywę niezniszczalności, ponieważ odnoszona jest bezpośrednio do rzeczywistości eschatologicznej: „Jak świecznik jasny objawiłaś się w ostatnich rodach światłem swoich cudów, nas oświecasz zawsze, Angelino sławna, i ciemność diabelską rozświetlasz" (stichera 1 na litii, t. 2).

Idea ciągłości stanowi punkt oparcia dla autonomizacji figury świętej, dzięki czemu może być przedstawiana nie tylko jako odbicie poprzedników na serbskich tronach, ale również matryca wytyczająca kurs następcom. Samoistność obrazu wyraża się poprzez identyfikację jej osoby z Pawłowym świętym korzeniem (Rz 11,16; WW, sedalen po 2 katyzmie, t. 4), zwyczajowo wykorzystywanym pośród symboliki mitów początku, teorii fundacyjnych, motywujących nadprzyrodzoną genezę opisywanych zjawisk. Takim korzeniem w Oficjum ku czci św. Jovana despoty jest św. Simeon, założyciel serbskiego państwa, organizator Cerkwi. Kontynuując sposób biblijnego przedstawienia, hymnograf ukazuje jak Angelina, odrośl od świętego korzenia, jednoczy się z korzeniem, zamienia w niego, rodzi i podtrzymuje wszystko, co z niej wyrasta i dalej się rozwija $(\mathrm{Rz} 11$, 17-18). Ona wydaje na świat i wychowuje synów, którzy stają się „pokarmem" dla serbskiego ludu (służba Jovanowi). W taki sposób za pośrednictwem Angeliny budowana jest wspólnota władców i narodu czerpiąca potencjał ze wspólnoty dynastii z jedynym prawdziwym założycielem i właścicielem serbskiej winnicy, Bogiem. Brankoviciowie, jak wcześniej Nemanjiciowie, zrodzona z Boga dynastia, sakralizują naród, nieprzerwanie nazywany Nowym Izraelem (WW, chwała t. 3) i świętym stadem (kanon IX, 4). Expressis verbis zespolenie wizji kontynuacji i nowego początku w postaci Angeliny wyraża lakoniczna pochwała świętej, zamieszczona pod jej ikoną w Srbljaku rimničkim: „Czcigodna matko, Angelino chwalebna, / dzieci i męża gorliwie wysławiwszy, / sama okazałaś się ich godna / widząc sławną ich śmieré".

Na obraz świętych władców, „ojców narodu”, składały się obowiązki wobec poddanych. Ten wizerunek za życia Angeliny sprowadza się do zadań opiekuńczych w duchu chrześcijańskiego miłosierdzia i pobożnego wychowania synów do świętych rządów nad nowym serbskim Izraelem. Koncepcja nadprzyrodzonego patronatu rozwija pełny ideał ,,matki” naro- 
$\mathrm{du}$, jej wizerunek definiują założenia narodowej tożsamości ustalonej od czasów Nemanjiciów, opartej na symfonii państwa i Cerkwi, prawosławnej wierze, miłości ojczyzny i służbie Kościołowi.

Angelina to uosobienie świętych monarchów i, według wzoru Bogurodzicy, orędowniczka za zbawienie świata (ikos po VI pieśni kanonu). Ukazano ją w figurach sternika łodzi miotanej burzą (kanon I, 4), archanioła Michała walczącego z Szatanem (między innymi: kanon, pieśń VI, 1), żołnierza Chrystusa ${ }^{9}$, strażnika domu (ikos), obrończyni prawej wiary (WW, sedalen po polieleju, t. 8), oświecicielki niewiernych (stichera 2 na litii, t. 2). Posiada koronne cechy wodza jako charyzmatyczne dary ducha, jest silna (kanon VII, 3) i niezwyciężona (WW, sedalen po polieleju, t. 8), kieruje się dobrem poddanych. Obrazy dynastycznego wstawiennictwa za lud powtarzają się $\mathrm{w}$ tekście kilkakrotnie. Ujmowane są w scenie deesis lub modłów zanoszonych do Boga przez Angelinę i resztę dynastii (kanon VI, 3; IX, 4). Jej wstawiennictwo pomaga w każdej potrzebie, służy uzdrowieniu chorych, pocieszeniu smutnych, chroni przed wrogiem, jest gwarancją pokoju (Павловић 1965: 154): „Przybywajcie wszyscy (...) prośby swoje z głębi duszy przynosząc, o darowanie od Boga łaski, kto o uzdrowienie z wszelakich chorób, kto o odpuszczenie grzechów, o wszystkie rzeczy, o otrzymanie których prosimy" (WW chwała, t. 8).

Kult zogniskowany jest wokół relikwii świętej i to one, jako widzialny dowód Bożej obecności wśród Serbów, dają gwarancję spełnienia obowiązków władczyni. Od początków państwa serbskiego relikwie miały polityczne i duchowe znaczenie; „Groby i relikwie stawały się swoistymi tarczami obronnymi, miejscami, gdzie naród zanosił prośby i składał podziękowania, gdzie chory odzyskiwał zdrowie; wreszcie były wertykalnym połączeniem płaszczyzn sacrum - profanum i horyzontalną linią wspólnoty" (Lis 2003: 107). O doniosłości doczesnych szczątków świętej mówi utożsamienie ich z arką przymierza (kanon VIII, 4), która jest nie tylko Bożym atrybutem, lecz także biblijnym znakiem władzy, siły obronnej, zwycięstwa (Lb, 35-36; $1 \mathrm{Sm} \mathrm{4,3).}$

Mauzoleum z ciałem świętej i pozostałych Brankoviciów ma znaczenie głównego ośrodka kultu, który gromadzi naród, jednocząc go wokół

9 „Siłę od Boga otrzymałaś, / by nieść zdrowie cierpiącym przez duchy nieczyste / i przeganiać duchy obłudne / w Boże wsparcie się uzbroiłaś i księcia ciemności starłaś", kanon VII, 3. Topos żołnierza obecny jest także w pieśni III, tropary 3 i 4. 
panującej dynastii we wspólnej wierze, Kościele, modlitwie, życiowym doświadczeniu $^{10}$, walce. Relikwie „ojca z synami, matki z dziećmi” są przedstawione niczym kwiat wonnej róży, której aromat otacza i uświęca wiernych (WW, chwała, ton 4). Posłannictwo duchowe władców otwiera się dodatkowo na zewnątrz, na inne kraje, także na żywioł nieserbski, nieprawosławny, by go integrować ze sobą lub z nim walczyć:

Wszystkie okoliczne ziemie i miasta, / przybądźcie do Nowego Izraela, / wspólnie się zgromadźmy / na cześć matki naszej Angeliny, / z radosną duszą i sercem / otoczmy cudowny jej grób, / łaskę uzdrowienia przyjmując / od łaski, która w niej żyje / ponieważ hojnie jej udziela / tym, którzy z wiarą do niej przybywają / i na wesele wzywa wszystkich rodaków, / by czcili święta jej pamięć, / tak do niej wołając: / Angelino czcigodna, / błogosławiony Stefanie, / Maksymie święty, / Jovanie sprawiedliwy, / stado wasze, które zebraliście / i Cerkiew, którą ukochaliście / chrońcie od napaści obcoplemiennych / i módlcie się za dusze nasze (WW, chwała, t. 3) $)^{11}$.

Uświęcony obecnością relikwii Brankoviciów, a później także kolejnych znamienitych serbskich przewodników duchowych - patriarchy Arsenija III Čarnojevicia, metropolity Isaji Đakovicia, patriarchy Arsenija IV Jovanovicia Šakabenty - Krušedol w wieku osiemnastym wyrósł na metropolię i duchowe centrum wojwodińskich Serbów (Слијепчевић 2002: 264).

Rozwijany we wszystkich kultach dynastii model rządów o cechach teokratycznych dostarczał nowej argumentacji do religijno-politycznego programu Cerkwi motywującego, rozpoczęty po utracie niepodległości w połowie piętnastego wieku, proces przejmowania przez Kościół funkcji państwowych $^{12}$. Świętość Brankoviciów jawiła się także jako swoiste narzędzie walki o umocnienie kościelnej władzy odnowionego patriarchatu w Peci, gdy wyznanie zaczęło stanowić „synonim państwowości” (Gil 2005: 76).

${ }^{10}$ Jako „chwała wiary i życia” poddanych, doznających nieszczęść i okrucieństwa, przemocy od „obcych”, Angelina personifikuje naród (kanon VI, 3; IX, 4; WW, chwała t. 3).

${ }^{11} \mathrm{Cf}$. chwałę w tonie 2 na małej wieczerni.

${ }^{12}$ Kolejni patriarchowie, realizując ideę zwierzchnika cerkiewnego jako etnarchy, nazywać się będą ,przywódcami politycznymi” i kontynuatorami dzieła Stefana Nemanji (Gil 2005: 75-77; Dąbrowska-Partyka 2004: 125). 
Obraz Angeliny stworzony przez autora Oficjum zakorzeniony jest w idei męczeństwa, którego wzorem była ofiara Lazara Hrebeljanovicia na Kosowym Polu. Nieugięta wiara w słuszność walki i ostateczne duchowe zwycięstwo, nagrodzone wieńcem chwały, będącym symbolem wiecznego błogosławieństwa (1 Kor 9,24-25; 2 Tm 4,6-8; Flp 3,14; 4,1) (Трифуновић (red.) 1970a: 35, 66), stały się nośne również w sensie ideologicznym. Osobiste zmagania świętej odnoszone są do warunków niewoli Serbów, którym w walce o zachowanie tożsamości religijnej i narodowej potrzebne są wartości reprezentowane przez Angelinę: ufność Bogu (wg Iz 40,31), jedność wiary, wspólnota Cerkwi i narodu, miłosierdzie, męstwo, wytrwałość w walce.

Idea boskości władzy w Oficjum św. Angelinie rzadko przejawia się bezpośrednio, znacznie częściej odnajdziemy ją w tzw. etykiecie sytuacyjnej i użytej symbolice, jaką wypracowano w wiekach wcześniejszych (Трифуновић (red.) 1970a: 45-46). One jednak stanowią o uniwersalizmie obrazu świętej mniszki-władczyni. Dzięki temu staje się centrum ideowo-duchowym serbskiej wspólnoty, symbolem utraconej państwowości, a także czynnikiem konsolidującym, co w chwilach niewoli umożliwiało zachowanie tożsamości narodowej przez kultywowanie pamięci o przeszłości, budzenie uczuć religijnych i patriotycznych, po odzyskaniu niepodległości natomiast podbudowywało ideologię państwową.

\section{Literatura}

Ћоровић В., 2001, Историја Срба, Ниш.

Dar stowa ze starej literatury serbskiej, 1983, wyb. i oprac. A. Naumow, przeł. T. Wątor-Naumow, W. Kotowiczowa, Łódź.

Dąbrowska-Partyka M., 2004, Literatura pogranicza, pogranicze literatury, Kraków.

Фајфрић Ж., 2013, Света лоза Бранковића, <http://www.rastko.org.rs/kosovo/istorija /zfajfric-brankovici_c.html\#_Toc486002752>, 15 kwietnia.

Gil D., 1995, Serbska hymnografia narodowa, Kraków.

Грујић Р., 1928, Павле, архиепископ пећки, w: Народна енщиклопедија СXC, ks. III, Загреб, s. 260.

Hryniewicz W., 1982, Chrystus nasza Pascha. Zarys chrześcijańskiej teologii paschal$n e j$, t. 1 , Lublin.

Lis I., 2003, Śmierć w literaturze staroserbskiej (XII-XIV wiek), Poznań. 
Lis I., 2004, Święci $w$ kulturze duchowej i ideologii Stowian prawostawnych $w$ średniowieczu (do $X V$ w.), Kraków.

Павловић Л., 1965, Култови лииа код Срба и Македонаща. Историјско-етнографска расправа, Смедерево.

Самарџић Р., Веселиновић Р., Поповић Т., 2000, Историја српског народа у 6 књига. Срби под туђинском влашћу 1537-1699, ks. 3, t. 1, Београд.

Слијепчевић Ђ., 2002, Историја Српске Православне Цркве, ks. I, Београд.

Спремић М., 1997, Бранковићи и Света Гора. Друга казивања о Светој Гори, Београд.

Томин С., 2009, Деспотища и монахиња Ангелина Бранковић - Света мајка Ангелина, Нови Сад.

Томин С., 2011, Мужаствене жене српског средњег века, Нови Сад.

Трифуновић Ђ. (red.), 1970а, О Србљьаку. Студије, Београд.

Трифуновић Ђ. (red.), 1970b, Србљак. Службе, канони, акатисти, ks. 3, przeł. Д. Богдановић, Београд. 
